\title{
Health promotion in the territory: strengths and challenges of local projects
}

\author{
Promoção da saúde no território: potências e desafios dos projetos locais ${ }^{a}$ \\ Promoción de la salud en el territorio: potencias y desafíos de los proyectos locales
}

Maria Benegelania Pinto ${ }^{1}$ (C) Kênia Lara Silva ${ }^{1}$ (C)

1. Universidade Federal de Minas Gerais. Belo Horizonte, MG, Brasil.
Corresponding author:

Autor: Maria Benegelania Pinto.

E-mail:benegelania@yahoo.com.br.

Submitted on 09/03/2018.

Accepted on 10/26/2018.

DOI: 10.1590/2177-9465-EAN-2018-0282

\section{Abstract}

Objective: to analyze actions of health promotion of a territory, trying to respond as they reveal the fundamental values, principles and guidelines of the National Health Promotion Policy (in Portuguese, Política Nacional de Promoção da Saúde). Method: a qualitative study, whose data were obtained from interviews with 11 members of a community network and submitted to the Textually Oriented Discourse Analysis. Results: Health promotion actions, which approximate those foreseen in the guidelines of the National Health Promotion Policy (in Portuguese, Politica Nacional de Promoção da Saúde), are mostly derived from the intersectoral work of the local community network; these harmonize with values, happiness, solidarity, as well as the principles of participation and territoriality. Conclusion: the restriction of the community's integrated participation in actions weakens the process of social transformation. It is necessary to review points such as the dissemination of the work carried out in partnership with the Network, as well as greater openness to the participation of the population in all stages of the actions developed in the territory. Implications for the practice: the study contributes to reflection on the limits and possibilities of intersectoral actions in the development of local projects and conduction of broad Health Promotion actions capable of producing citizenship.

Keywords: Health Promotion; Community Participation; Public Policy; Intersectorial Collaboration.

\section{REsUMO}

Objetivo: analisar as ações de promoção da saúde de um território, procurando responder como elas revelam os valores fundamentais, princípios e as diretrizes da Política Nacional de Promoção da Saúde. Método: estudo qualitativo, cujos dados foram obtidos através de entrevistas com 11 membros de uma rede comunitária, e submetidos à Análise de Discurso Textualmente Orientada. Resultados: as ações de promoção da saúde, que aproximam daquelas previstas nas diretrizes da Política Nacional de Promoção da Saúde, decorrem na sua maioria do trabalho intersetorial da Rede comunitária local; essas compatibilizam com os valores, felicidade, solidariedade, assim como os princípios de participação e territorialidade. Conclusão: a restrição quanto à participação integrada da comunidade nas ações fragiliza o processo de transformação social. Faz-se necessário rever pontos, como a divulgação dos trabalhos realizados em parceria com a Rede, assim como uma maior abertura à participação da população em todas as etapas das ações desenvolvidas no território. Implicações para a prática: o estudo contribui para reflexão sobre limites e possibilidades de ações intersetoriais no desenvolvimento de projetos locais e na condução de ações de Promoção da Saúde amplas, capazes de produzir cidadania.

Palavras-chave: Promoção da Saúde; Participação da Comunidade; Políticas Públicas; Intersetorialidade.

\section{Resumen}

Objetivo: analizar las acciones de promoción de la salud de un territorio, buscando responder como ellas revelan los valores fundamentales, principios y las directrices de la Política Nacional de Promoción de la Salud (en portugués, Política Nacional de Promoção da Saúde). Método: estudio cualitativo cuyos datos fueron obtenidos a través de entrevistas con 11 miembros de una red comunitaria y sometidos al análisis de discurso textualmente orientado. Resultados: las acciones de promoción de la salud, que se aproximan a las previstas en las directrices de la Política Nacional de Promoción de la Salud (en portugués, Política Nacional de Promoção da Saúde) derivan en su mayoría del trabajo intersectorial de la Red comunitaria local; esas compatibilizan con los valores, felicidad, solidaridad, así como los princípios del participación y territorialidad. Conclusión: la restricción en cuanto a la participación integrada de la comunidad en las acciones debilita el proceso de transformación social Se hace necesario revisar puntos como la divulgación de los trabajos realizados en asociación con la Red, así como una mayor apertura a la participación de la población en todas las etapas de las acciones desarrolladas en el territorio. Implicaciones para la práctica: el estudio contribuye a reflexionar sobre límites y posibilidades de acciones intersectoriales en el desarrollo de proyectos locales y la conducción de acciones de promoción de la salud amplias, capaces de producir ciudadanía.

Palabras clave: Promoción de la Salud; Participación de la Comunidad; Políticas Públicas; Colaboración Intersectorial. 


\section{INTRODUCTION}

The discussion on health promotion has been strengthened in the world setting with proposals to redefine public policies, directing a new look at the context of health, starting from the understanding that biomedical devices are not able to modify the determinants and social determinants of the health-disease process $^{1,2}$.

The Ottawa Conference, held in Canada in 1986, presented a milestone on the idea of multiple health accountability. From then on, the individual responsibility for the importance of people taking over their lives and making choices that are better for themselves, as well as the State's responsibility in the development of public policies capable of improving social conditions ${ }^{3,4}$.

In Brazil, health promotion was incorporated as a public policy, becoming an integrated, transversal strategy, making the social determinants of population health, besides of proposing the creation of mechanisms to defend participation and social control, in addition to intersectoriality ${ }^{5}$. With the promulgation of the National Health Promotion Policy (in Portuguese, Política Nacional de Promoção da Saúde (PNPS)), the State's commitment to expanding and qualifying actions in the services and management of the Brazilian Unified Health System (SUS - Sistema Único de Saúde) is established in the national setting, reaffirming the promotion of health care, such as all places where human care activities are carried out, whether in health services or other spaces, such as squares, schools, community territories, among others ${ }^{6}$.

The actions of health promotion should be quite varied in terms of focus, object, emphasis and fields of action, considering the different contexts for its accomplishment. In relation to the focus, actions can be directed to individuals, specific groups of the population or the general population. As for the object, they can cover a single health problem, sensitive to promotion actions, or be comprehensive, proposing to address the social determinants of health as a whole?

Considering the emphasis, actions can be educational or more comprehensive, involving quality of life and development aspects. Finally, considering the field of action means that these actions can either be rallying of a single field of action (healthy public policies; strengthening community action; development of personal skills; reorientation of the health system and the creation of health-friendly environments) or include, simultaneously, several of them ${ }^{7}$.

Strengthening of actions for the construction and mobilization of resources for life is an indispensable issue for the promotion of health. To do so, they must be based on fundamental values: solidarity, happiness, ethics, respect for diversity, co-responsibility; principles of equity, participation, autonomy, empowerment, intersectoriality, sustainability, comprehensiveness and territoriality; in addition to being compatible with the guidelines: to boost intersectoral actions and strengthen social participation, as proposed in the National Health Promotion Policy ${ }^{8}$.

In this perspective, this study aimed to analyze actions to promote the health of a territory, trying to respond as they reveal the fundamental values, principles and guidelines of the National Health Promotion Policy.

\section{METHOD}

This is a qualitative research, anchored in the framework of Historical and Dialectical Materialism ${ }^{9}$. This framework was chosen for the adequacy of its postulates and tools to the study object. Its assumption is that nothing is eternal, absolute or fixed, whether in the natural world or in the social world, for everything is in permanent transformation and submitted to the movement of history.

In materialistic dialectics, knowledge and theories of knowledge are presented as historical expressions that are based on three principles: contradiction, tension and overcoming. The contradiction expresses the idea that the struggle of opposites is immanent to the identity of phenomena. Tension states that between any form and what it is, there is also the becoming. The overcoming is based on the idea that evolution emanates from an earlier stage less developed and that this results from the contradiction?.

Analyzing actions for health promotion, in this perspective, is to understand health beyond individual, biological and behavioral issues, but as a process determined by the social and economic conditions of each era and each context, built historically. It is supposed to analyze this object, trying to reveal the contradictions existing between the form and the content, between the appearance and the essence, between the singular, the particular and the structural.

The study was carried out in a neighborhood in the Western Zone of the municipality of João Pessoa, Paraíba, Brazil, from February to July 2017. The territory is characterized as being of great social vulnerability, has riverside communities, high levels of social inequality and violence, especially due to drug trafficking.

In the community there is a community Network that promotes and supports actions with educational, health and assistance focus, through thematic projects aimed at the public of schools, as well as major mobilization events that occur throughout the year in the territory. The actions are facilitated by the individual and intersectorial work of the actors of the different institutions belonging to the collective, among them, the governmental ones (municipal and state schools, municipal daycare, Basic Health Unit - UBS, Social Assistance Reference Center - CRAS (in Portuguese, Centro de Referência em Assistência Social) and Non-Governmental Organizations (representatives of civil society and). Among the Non-Governmental Organizations, the Community Development Committee (CDC) of a cement factory, active in the territory for approximately four years, is cited mainly for the financing of social projects in the community.

Of the 15 members of the community network, 11 participated in the study because they met the selection criterion: to have more than six months of association with the collective and to have no more than two consecutive absences at meetings of the 
Network. Of the participants, four were residents of the territory, six represented governmental organizations and five were Non-Governmental Organizations. The contact with the participants occurred by means of an individual invitation during the monthly meetings of the Network, which happened in the CRAS of the neighborhood.

Data collection was carried out through semi-structured interviews and participant observation in some of the meetings of the Network and the actions of health promotion in the territory, recorded as Field Journal (FJ), where the moments of planning, implementation and evaluation of observed actions; the types of proposed actions, partners involved, besides those characteristics that revealed the principles and guidelines of the PNPS.

The interviews were conducted by a script containing the following questions: 1) What health promotion actions are developed in the territory (in community spaces such as schools, squares, etc.)? 2) Discuss the participation of each institution and community in these activities. The interviews took place individually and the privacy of the respondents was observed. In respect of anonymity, an alphanumeric code was used to identify the lines, which shows the initials of each participating organization, followed by the number that indicates the order of the interview. Thus, representatives of government organizations were given the acronym "RGO" and representatives of Non-Governmental Organizations "RNGO".

The analysis process was carried out by the Textually Oriented Discourse Analysis (TODA), in Norman Fairclough's proposal. As a methodological reference, the TODA is located in the tradition of qualitative research, mainly due to the focus on the detailed analysis of texts and discourses, for the debate of a certain social problem, making its contribution regarding the reflection on the same, the emancipation of the subjects of the dominant forms, through explanatory criticism and self-reflection ${ }^{10-11}$.

The three-dimensional model of TODA distinguishes three dimensions of discourse: text, discursive practice and social practice. The analysis of the text is detailed in categories of textual analysis, that is, forms and meanings textually associated with ways of representing, interacting and identifying themselves in situated social practices and that help in the mapping of the dialectical relations between the discursive and the social, allowing the investigation of the characteristic effects of texts in social practice, and vice versa; the discursive practice varies among the different types of discourse, being determined by the intricate social factors, the processes of production, distribution and consumption of the text, and the analysis of the social practice, which is related to the ideological and hegemonic aspects in the analyzed discursive instance ${ }^{11}$.

In order to operationalize the analysis, a scheme was constituted of three stages: in 1. Transcription of the data - the organization of the textual corpus was processed; followed by 2 . Coding and categorization of the data with the selection of textual fragments that presented the greatest recurrence and the identification of discursive elements that used ideological meaning to the participants' speeches, and finally, 3. Explanatory criticism through which the critical alternatives to counter the speeches materialized in the speeches of the participants. Thus, the article portrays the category of Health Promotion Actions in the Territory: Focus, Object, Emphasis and Field of Action, which, together with 3 other categories, composes the material treated in a Doctoral Thesis. It was decided to present in this text only one category by the extension of the material.

The study respected the formal requirements contained in the national 12 and international regulatory standards for research involving human beings, CAAE: 60902216.5.0000.5149, with favorable Opinion1.913.074, by the Research Ethics Committee with Human Beings of the Universidade Federal de Minas Gerais in 06 February 2017.

\section{RESULTS}

Among the health promotion actions identified in the study, some presented a more rallying/articulating character, especially those that are part of the calendar of community events, such as the Semana do Bebê (freely translasted as Baby Week), the Dia do Bem Fazer (freely translasted as Well-Doing Day) and the Feira de Cultura, Educação, Saúde e Arte (freely translasted as Culture, Education, Health and Art Fair) (CEART), all carried out throughout the year in the territory.

Schools are the setting for carrying out health promotion actions of a more educational nature, restricted to the student public, sometimes with the participation of parents and/ or guardians. These include hygiene actions, the Semana da Alimentação Saudável na Escola (freely translated as Healthy Eating Week at School), the activities of the Programa Saúde na Escola (freely translated as School Health Program) (PSE) and projects supported by the Network, such as the ProjetoTecendo uma Cultura de Paz nas Escolas (freely translated as Building a Culture of Peace at Schools Project). Chart 01 summarizes the actions of health promotion identified in the context of the community and in schools.

\section{HEALTH PROMOTION ACTIONS IN THE TERRITORY: FOCUS, OBJECT, EMPHASIS AND FIELD OF ACTION}

The Baby Week is an event that involves a set of activities focused on early childhood that occurs annually for seven days in the month of May. Considering the principles and values of health promotion, it is perceived that the action adds co-responsibility, participation and intersectoriality. (FJ 01 - observation in the municipal school and territory on 05/23/2017).

Baby week is a whole week. We have the opening and have the finalization. There, it works with families; it has themes that work with the professionals that are part of the Network. He works inside the Daycare with shantala workshops, storytelling, works with schools, with Non-Governmental Organizations because they also have 
Chart 1. Overview of health promotion actions in the studied territory, João Pessoa, Paraíba, Brazil

\begin{tabular}{c}
\hline ACTIONS CARRIED OUT IN \\
THE CONTEXT OF THE COM- \\
MUNITY*
\end{tabular}

\begin{tabular}{l}
\hline - BABY WEEK \\
\hline Focus: group. \\
Object: unique and com- \\
prehensive. \\
Emphasis: educational; of \\
quality of life and develop- \\
ment actions.
\end{tabular}

Action field: development of personal skills; strengthening community action.

\section{- WELL-DOING DAY**}

Focus: all population. Object: comprehensive. Emphasis: quality of life actions.

Action field: strengthening community action and developing healthy environments.

\section{- CEART}

Focus: all population.

Object: unique and comprehensive health problems. Emphasis: educational and quality of life actions. Action field: strengthening community action and developing healthy environments.

\section{- BUILDING A CULTURE OF PEACE AT SCHOOLS PRO- JECT \\ Focus: all population. Object: comprehensive. Emphasis: educational ac- tions. \\ Action field: development of $p$ ersonal skills, streng- thening community action and developing healthy environments.}

Note:

*Data produced from the field journal records

**Actions not observed during the data collection period but described in the participant's study. children and adolescents and families. It encompasses everyone, in these spaces, in schools, in the Social Assistance Reference Center. (RNGO 04).

Well-Doing Day is an idealized action funded by the Community Development Committee of the cement factory. It targets the general population and counts with the support of the Network in the activation of neighborhood institutions for community mobilization and participation in the project activities, which consist of voluntary work to operate structural improvements in community spaces such as schools, daycare centers, squares, etc. (There was no observation because the action occurred after the period of data collection).

At Well-Doing Day, for example, we call volunteers, call parents, mothers, employees to volunteer. So every school, every institution gets this part of hosting volunteers, picking up volunteers, isn't it? That is, it is a social work to involve the community. It works a lot with the awareness where the company invests in an area, the community receives that investment. But, you get paid to take care. You receive for usufruct, but you also get paid to take care. (RNGO 08).

The Culture, Education, Health and Art Fair is organized by the Network through the state apparatus that acts in the community. Their actions have unique object, when it directs to the control of the diseases and aggravations. However, they are also comprehensive when they connect with determinants, such as culture and leisure activities. In this sense, it is possible to identify values, happiness, solidarity, as well as the principles of participation, intersectoriality and territoriality as part of these actions. (FJ 02 - observation around schools on 07/13/2017).

\begin{abstract}
Moms and parents come because they want to see the awards. We do writing contest, poetry contest. So, always on that day, it's the day that we try to honor who really deserves this honoring. And we give them this freedom to choose what they want to present: music, dance, theater, whatever. They like it so much. (RGO 03).
\end{abstract}

As for the subject of the actions, those identified as individual and group are carried out at school and tend to a single health problem, such as the activities of the School Health Program and the approach to cross-cutting themes such as Healthy Eating Week at School, activity planned in the school calendar. (FJ 03 - observation at the municipal school on 04/24/2017; FJ 04 - observation at the state school on 06/16/2017).

The actions have the partnership with the family health unit that makes periodic visits is, weekly, monthly. And, in our planning, as I have already said, people, in cross-cutting themes, for example, have a very intensive work 
on that too: work with STD. Let's suppose: in this bimester we choose a week to talk about personal hygiene, personal body hygiene, body hygiene. (RGO 02).

Within the annual curriculum there are also the projects. Then there's also the food. So they also deal with them on the issue of healthy eating that is very difficult nowadays. It's an issue you teach one way and the family comes from another, right? The family sends stuffed biscuits, despite having snacks at school. But there are mothers who send popcorn, snacks, those things that we know are not healthy, right? (RGO 01).

The actions of hygiene in the school happen in attention to the demands of the students, when they present commitment of the corporal hygiene and diseases of skin. Hygiene presented itself as a theme strongly associated with health in the speeches of participants representing the school. These findings indicate an interdiscursive aspect that rescues the discourse of school hygiene as something still reproduced and naturalized in the speeches of the participants, despite the possibility of thinking about health in an extended way, in the current context.

[...] body hygiene, right? Personal hygiene, right? The main thing that people think so is where they have to talk more ... right? Because boys come sometimes without bathing, anyway ... then we'll start right there, putting them in that context... [...] let's suppose in this bimester we choose a week to talk about personal hygiene, body hygiene, personal, body hygiene, there everything we can bring and do so, show, present, to attract the student's attention we do demonstrations, exhibitions of some things [...] (RGO 05).

[...] we also remind them and sometimes have very serious individual cases regarding hair hygiene, right? Of teeth ... of the body, such ... and then until last week we even called a mother to talk about all this [...] (RGO 11).

The Building a Culture of Peace at Schools Project a can be considered an initiative favorable to health promotion at school, in a broad and participatory perspective. This project was conceived by one of the Non-Governmental Organizations represented in the Network, and its programming proposed the discussion of expanded themes, which interface with social determinants such as: ethnicity, race, respect for diversity, gender and sexuality, mediation of conflicts and practice of restorative justice. In its structuring, it had workshops aimed at teachers, students and parents/guardians. (FJ 05 - observation at the municipal school on 05/06/2017; FJ 06 - observation at state school on 06/21/2017).

The peace culture project is health promotion. I see the work of Non-Governmental Organizations here within schools, in general the network itself. It is health promo- tion when you come together to think strategies [...] For example, there are a lot of teenagers that I realize they are welcome, that they are homosexual, that in the general context are very excluded and they are being very receptive and showing their full potential. You already have a health promotion, right? So that the only alternative of an LGBT is not prostitution, a sexual exploitation, in the case of children and adolescents. But we know that sometimes the ones from only low class are exploited, right? (RNGO 09).

With regard to the fields of action proposed by the Ottawa Charter, it was possible to note that the actions carried out in the territory favor: Strengthening community action; Development of personal skills and the favoring of environments to health. In this way, they present the potential to be compatible with the principles, values and guidelines of the National Health Promotion Policy.

\section{DISCUSSION}

The main characteristic of the health promotion actions in the studied territory, which approximate those provided for in the guidelines of the National Health Promotion Policy, was related to the intersectorial network work. Far from being the definitive answer to the problem of health inequities in the territory, networking prevents duplication of actions, as well as articulating resources, ideas and skills in favor of priority projects.

Social and community networks are of particular importance in the field of health promotion, especially in favor of participatory and integrated processes in the advocacy and formulation of urban public policies involving the State and society ${ }^{13}$.

Events such as Baby Week, Well-Doing Day and Culture, Education, Health and Art Fair report joint responsibility, participation and intersectoriality, principles and values of health promotion. These actions reveal that networking is also an exercise in the sharing of power, social, political and solidarity protagonism ${ }^{13}$.

As a PNPS principle, intersectoriality refers to the "articulation of knowledge, strengths and experiences of individuals, groups and sectors in the construction of shared interventions, establishing bonds, co-responsibility and co-management for common objectives" 14 . Thus, it presents itself as a strategy capable of accounting for the challenges posed by a multi-causal health-disease process as a cross-cutting element in the practices recommended in the public policy documents that are based on SUS proposals ${ }^{15}$.

PNPS contributes to the articulation of intersectoral public policies in national and international agendas ${ }^{14}$. In this perspective, it is possible to affirm that it dialogues with other policies, such as the Política Nacional de Atenção Básica (freely translated as National Policy on Primary Care), the Politica Nacional de Educação Popular (freely translated as National Policy on Popular Education) and the Política Nacional de Gestão Estratégica e Participativa (freely translated as National Policy on Strategic 
and Participatory Management), for articulating, among other points, co-responsibility and participation, with a view autonomy and social control, through the empowerment of the populations.

In the direction of an action based on intersectoriality, local plans and interventions must be expressions of relations that occur simultaneously, since such expressions encourage autonomy and empowerment, awakening the population to prioritize actions that highlight the problems recognized by all, giving visibility to the contexts and boosting creative solutions to their problems ${ }^{16}$.

As a comprehensive part of the Network, the apparatus of the territory, especially the schools, are the great mobilizers of the community in the actions, attesting to the Network as an influential collective in the territory. However, it was not possible to visualize the population engagement in the planning and evaluation moments of the actions, allowing to affirm that the participation of this one is still restricted. In addition to this fact, there seems to be a perception that it is the Network that "does for the community", or rather "with the community", according to discursive aspects in the excerpts from the statements of RNGO 08 and RGO 03.

Likewise, the lack of accent on the Network for an actor who formally represents the community raises the question of the validation of this as collective council of the neighborhood. Although some inhabitants of the territory are part of their formation, they represent institutional interests, pointing out a gap to be filled regarding social participation.

In this perspective, intersectoriality is limited when so-called collective plans do not consider the real participation of representatives of the community in the process as a whole, that is, from the moment of the conception of the action until its actual performance. Thus, the participation of the community is restricted to validate what is decided in a previous moment by the leaders of the apparatuses operating in the territory ${ }^{16}$.

On the other hand, giving a seat and voice to the local actor is to recognize their value, which causes a movement towards transformation. It also means knowing that the motivation for the formation of networks starts from the knowledge of the individual and collective desires in a given territory as an essential facilitator in solving the complex problems of the community ${ }^{16}$. Therefore, intersectoriality must be understood as a device that provides for meetings, listening and otherness, helps to expose divergent interests, tensions and, often, impossible convergences themselves ${ }^{15}$.

The configuration of networking in the territory seems to also function as a mobilizer of personal, social and institutional relations, since the apparatuses, when aggregated, have their potential amplified and reverberate positively not only in the work of the institutions themselves, but of these with the others and in the community as a whole.

However, although the actions are planned and carried out through the partnerships established among the members of the Network, it is contradictorily observed that there is a tendency to reproduce the traditional conception, with programming that favors actions of a more assistance character, whose participa- tion of the community, most of the time, is summarized to the receipt of the actions.

In relation to the emphasis of the actions, in general, they assume an educational character, as the workshops of the projects carried out in the schools as in other spaces of the community. From the perspective of the individual focus, the most important are those actions that assume hygienic characteristics.

As an institution, the school is defined by its pedagogical character in the teaching function. Health, in this context, is a recurrent theme of learning. It is not new, however, that in the trajectory of health education, a hygienist and preventive logic persisted, with normative components and predefined contents on what should be done and discussed in Health, a logic that persists strongly until now ${ }^{17-18}$.

In this way, tensions and contradictions regarding the potential of the school as a space for the transformation of realities with the predominance of the reproduction of actions that reflect the discourse that maintains the hegemonic thinking of the clinic in this scenario. Evidence of this analysis is perceived in RGO 02's speech when referring to the health actions that happen in school, only by the logic of school hygiene and the clinical component of the PSE.

Similarly, study findings ${ }^{19}$ relate the tendency to maintain the clinical paradigm, associated with the conception and practices of health promotion in primary health care services, whose conceptions/actions on health promotion are based on the biomedical model of disease prevention, or by the model promulgated in the Ottawa Charter. In the first situation, actions are restricted to the health sector and are focused on curing and preventing illness. While in a broader dimension of health, there are the interdisciplinary and intersectoral ones that approach the concept of quality of life.

Still in the context of the school, in the group approach, the actions focus mainly on the adolescents and are related to the themes of risk prevention and illness. In this perspective, the majority of the activities of the Health Program in the School, besides the projects directed to Healthy Eating Week at School.

The School Health Program presents important limitations to address the complex problems of health of students, with their sporadic actions that prioritize only prevention and risk, to the detriment of the determinants of the health-disease process. Breaking with this paradigm is still a challenge in many aspects, from the pedagogical to the insertion of active methodologies that allow the problematization of social determinants through criticism and reflection ${ }^{20-21}$. Dialectically, it also includes the ideological challenge, based on the construction of discourses that value autonomy, participation, co-responsibility, as well as the understanding of health as a right to be assured by the State, according to PNPS principles, values and guidelines.

It was possible to identify, at school, actions aimed at favoring healthy habits and behavior change, as evidenced in the Healthy Eating Week at School. In this context, the discursive analysis revealed that there is a negative representation of the family's eating habits, pointed out as the main obstacle in adop- 
ting a healthy eating practice, which appears as an ideological component in the RGO 01 statement.

Also noteworthy is the lack of mention of cultural issues, as well as the influence of income on the acquisition of healthy foods in the participant's speech. This silencing attests to the school as a space of maintenance of the dominant thought that considers health disconnected from the social and express the contradictions in the school-community relation for the construction of health promotion.

On the other hand, the participation of the school in the Network is an indication of the institution's opening to new possibilities to think about its problems from a broader perspective, focused on the reality of its environment. In this sense, it receives the projects developed in partnerships with Non-Governmental Organizations and contributes to the discussion of social determinants, betting on the formation of protagonists in their context, which may favor the formation of new discourses. This process happens dialectically in tension-overcoming movements, allowing reaching a new perspective on the expanded conception of health, as well as social participation, pointing out new ways to think and produce health promotion in school.

From these initiatives, strategies with the potential to overcome the discourse that validates the paradigm of the clinic emerge and base health as an individual responsibility, by providing more focused actions in the context of the school, such as the Building a Culture of Peace at Schools Project.

In addition to being a good opportunity to problematize the complex issues that involve the school and its environment, by including families in the workshops, the project provides a dialogical relationship with possibilities to critique reality and elaborate new conceptions about the health-illness process, favoring the principles of empowerment, autonomy and social participation.

In this sense, the present study ${ }^{22}$ stresses the importance of the role played by schools as conductors of health policies, as in the case of the Health Permanent Education policy, since the principles and values of health promotion permeate it, catalyzing their capacity to mobilize of different social agents, in the development of transformative actions.

The Network, once again, gains expressiveness in intersectoral work, by articulating different institutions to the school, expanding its potential as strategies to organize the actions of health promotion in the scenery of the territory ${ }^{23}$.

Intersectoriality disregards co-responsibility, participation and autonomy of the partners in solving collective problems. When one of these does not correspond or assumes the role of the other, we have overlapping functions and absences that weaken partnerships and render strategies for solving complex problems and transforming realities.

Networking cannot substitute for the role of the State; rather, it should enhance the initiatives developed as a right to citizenship and social protection. In this sense, the actions designed by the collective studied are not intended to solve the problem of the absence of the State in the territory, but end up putting a lens on it, revealing aspects that need to be improved.

\section{CONCLUSION}

The intersectorial potential of health promotion actions developed in the territory, based on networking, is compatible with the values, principles and guidelines of the National Health Promotion Policy, which implies the need to review the points that need to be improved and strengthened in the reality of the context studied. Among these issues, the links between institutions participating in the network stand out; the broader dissemination of the work performed by it in the community, as well as greater openness to the participation of the population, especially those who are not yet represented as members of this collective.

It was possible to perceive the articulating/mobilizing potential of the school when it is activated by the Network, as well as the potential of intersectorial network work as a catalyst for actions in this scenario. However, it is necessary for the actors of the school to realize that their role also concerns the autonomy to design strategies to face their problems, from their own reality. The study has as a limitation the fact of being a local cut. Larger studies are desirable, including scenarios in more diverse realities.

\section{FNIANCIAL SUPPORT}

This study had a PhD grant awarded by the Coordination for the Improvement of Higher Education Personnel (in Portuguese, Coordenação de Aperfeiçoamento de Pessoal de Nível Superior (CAPES)), from August 2017 to March 2018.

\section{REFERENCES}

1. Pinheiro DGM, Scabar TG, Maeda ST, Fracolli LA, Pelicioni MCF, Chiesa AM. Competências em promoção da saúde: desafios da formação. Saúde Soc [Internet]. 2015;24(1):180-8. Available from: http://www. scielo.br/pdf/sausoc/v24n1/0104-1290-sausoc-24-1-0180.pdf. DOI: http://dx.doi.org/10.1590/S0104-12902015000100014

2. Carvalho FFB, Cohen SC, Akerman M. Refletindo sobre o instituído na Promoção da Saúde para problematizar 'dogmas'. Saúde Debate [Internet].2017;41(3):265-76. Available from: http://www.scielo.br/scielo. php?pid=S0103-11042017000700265\&script=sci_abstract\&tlng=pt. DOI: http://dx.doi.org/10.1590/0103-11042017s320

3. López-Fernández LA, Hormazábal OS. Repensar la Carta de Ottawa 30 años después. Gac Sanit [Internet]. 2017 Nov/Dec;31(6):443-5. Available from: http://dx.doi.org/10.1016/j.gaceta.2016.12.013

4. Malta CD, Morais Neto OL, Silva MMA, Dais R, Castro AM, Reis AAC Akerman M. Política Nacional de Promoção da Saúde (PNPS): capítulos de uma caminhada ainda em construção. Ciênc Saúde Coletiva [Internet]. 2016;21(6):1683-94. Available from: http://www.scielo.br/ pdf/csc/v21n6/1413-8123-csc-21-06-1683.pdf. DOI: http://dx.doi. org/10.1590/1413-81232015216.07572016

5. Silva PFA, Baptista TWF. A Política Nacional de Promoção da Saúde: texto e contexto de uma política. Saúde Debate [Internet]. 2015; 39(no.esp):91-104. Available from: http://www.scielo.br/scielo. php?pid=S0103-11042015000500091\&script=sci_abstract\&tlng=pt. DOI: http://dx.doi.org/10.5935/0103-1104.2015S005327

6. Buss PM, Chamas C, Faid M, Morel C. Desenvolvimento, saúde e política internacional: a dimensão da pesquisa \& inovação. Cad Saúde Pública [Internet].2016;32(Supl 2):e00046815. Available from: http://www.scielo. br/pdf/csp/v32s2/pt_1678-4464-csp-32-s2-e00046815.pdf.DOI: http:// dx.doi.org/10.1590/0103-311X00046815 
7. Buss PM, Carvalho Al. Desenvolvimento da promoção da saúde no Brasil nos últimos vinte anos (1988-2008). Ciênc Saúde Coletiva [Internet].2009 Dec; [cited 2018 Jan 20]; 14(16):2305-16. Available from: www.scielo.br/ scielo.php?script=sci_arttext\&pid=\$1413-81232009000600039

8. Ministério da Saúde (BR). Secretaria de Vigilância em Saúde. Política Nacional de Promoção da Saúde. Revisão da Portaria n 687 MS/GM, de 30 de março de 2006. Aprova a Política de Promoção da Saúde. Brasília (DF): Ministério da Saúde; 2014. Available from: http://bvsms. saude.gov.br/bvs/publicacoes/pnps_revisao_portaria_687.pdf

9. Cheptulin A. A dialética materialista: categoria e leis da dialética. 2a ed. São Paulo: Alfa-omega; 2004.

10. Magalhães I, Martins AR, Resende VM. Análise de discurso crítica: um método de pesquisa qualitativa. Brasília: Universidade de Brasília;2017.

11. Ramalho V, Resende VM. Análise de discurso (para a) crítica: $O$ texto como material de pesquisa. 2a ed. Campinas: Pontes; 2016.

12. Conselho Nacional de Saúde (BR). Resolução 466, de dezembro de 2012. Estabelece diretrizes e normas regulamentadoras de pesquisa envolvendo seres humanos. Brasília (DF): Conselho Nacional de Saúde; 2012.

13. Mendes R, Bogus CM, Westphal MF, Fernandez JCA. Promoção da saúde e redes de lideranças. Physis [Internet]. 2013;23(1):20926. Available from: http://www.scielo.br/scielo.php?pid=S010373312013000100012\&script=sci_abstract\&tlng=pt. DOI: http://dx.doi. org/10.1590/S0103-73312013000100012

14. Bueno RE, Moysés ST, Bueno PAR. Diálogos intersetoriais: pontes estabelecidas na revisão da política nacional de promoção da saúde. Rev Eletr Interdisc [Internet]. $2017 \mathrm{Jul} / \mathrm{Dec} ; 10(2): 51-9$. Available from: https:// revistas.ufpr.br/diver/article/view/52893. DOI: http://dx.doi.org/10.5380/ diver.v10i2.52893

15. Akerman M, Sá RF, Moyses S, Rezende R, Roch D. Intersetorialidade? IntersetorialidadeS! Ciênc Saúde Coletiva [Internet].2014;19(11):4291300. Available from: http://www.scielo.br/pdf/csc/v19n11/14138123-csc-19-11-4291.pdf. DOI: http://dx.doi.org/10.1590/1413812320141911.10692014

16. Moysés ST, Franco de Sa R. Planos locais de promoção da saúde: intersetorialidade(s) construída(s) no território. Ciênc Saúde Coletiva [Internet]. 2014;19(11):4323-30. Available from: http://www. scielo.br/scielo.php?pid=S1413-81232014001104323\&script=sci abstract\&tlng=pt. DOI: http://dx.doi.org/10.1590/1413812320141911.11102014
17. Silva CS, Bodstein RCA. Referencial teórico sobre práticas intersetoriais em Promoção da Saúde na escola. Ciênc Saúde Coletiva [Internet]. 2016;21(6):1777-88. Available from: http://www. scielo.br/scielo.php?pid=S1413-81232016000601777\&script=sci abstract\&tIng=pt. DOI: http://dx.doi.org/10.1590/141381232015216.08522016

18. Vieira AG, Aerts DRGC, Câmara S, Schubert C, Gedrat DC, Alves GG. A escola enquanto espaço produtor da saúde de seus alunos. Rev Iberoam Estud Educ [Internet]. 2017; [cited 2018 Jan 20]: 12(2);916-32. Available from: https://dialnet.unirioja.es/descarga/ articulo/6202985.pdf

19. Gurgel MGI, Alves MDS, Moura ERF, Pinheiro PNC, Rêgo RMV Promoção da saúde no contexto da estratégia saúde da família: concepções e práticas da enfermeira. Esc Anna Nery [Internet]. $2011 \mathrm{Jul} / \mathrm{Sep} ; 15(3): 610-5$. Available from: http://www.scielo.br/scielo. php?script=sci_arttext\&pid=S1414-81452011000300024. http:// dx.doi.org/10.1590/S1414-81452011000300024

20. Carvalho FFB. A saúde vai à escola: a promoção da saúde em práticas pedagógicas. Physis [Internet]. 2015;25(4);1207-27. Available from: http://www.scielo.br/scielo.php?pid=S0103$73312015000401207 \&$ script=sci_abstract\&tlng=pt. DOI: http:// dx.doi.org/10.1590/S0103-73312015000400009

21. Silva KL, Sena RR, Akerman M, Belga SMM, Trevenzoli AR. Intersetorialidade, determinantes socioambientais e promoção da saúde. Ciênc Saúde Coletiva [Internet]. 2014; 19(11):436170. Available from: http://www.scielo.br/pdf/csc/v19n11/14138123-csc-19-11-4361.pdf. DOI: http://dx.doi.org/10.1590/1413812320141911.10042014

22. Cardoso MLC, Costa PP, Costa DM, Xavier C, Souza RMP. A Política Nacional de Educação Permanente em Saúde nas Escolas de Saúde Pública: reflexões a partir da prática. Ciênc Saúde Coletiva [Internet]. 2017; 22(5):1489-500. Available from: http://www.scielo. br/pdf/csc/v22n5/1413-8123-csc-22-05-1489.pdf. DOI: http://dx.doi. org/10.1590/1413-81232017225.33222016

23. Régis-Aranha LA, Moraes FH, Santos STC, Heufemann NEC Magalhães WOG, Zacarias Filho RP, et al. Acuidade visual e desempenho escolar de estudantes em um município na Amazônia brasileira. Esc Anna Nery [Internet]. 2017;21(2):e2017003. Available from: http://www.scielo.br/pdf/ean/v21n2/1414-8145 ean-21-02-e20170032.pdf. DOI: http://dx.doi.org/10.5935/14148145.20170032

\footnotetext{
a Article extracted from the doctoral thesis "Relação escola e comunidade: desenvolvendo competências para a promoção da saúde", defended by the first author in the Graduate Program in Nursing, Universidade Federral de Minas Gerais, 2018, under the guidance of the second author.
} 